\title{
THE SCOPE OF GENETIC ALGORITHMS IN DEALING WITH FACILITY LAYOUT PROBLEMS
}

\author{
A. Kundu ${ }^{1 *}$ and P.K. Dan ${ }^{2}$ \\ 1, 2 Department of Industrial Engineering \& Management \\ West Bengal University of Technology, India \\ anirbankundu127@yahoo.com, dan1pk@hotmail.com
}

\begin{abstract}
The paper presents a state-of-the-art review of the application of the Genetic Algorithm (GA), an important methodology in facility layout problems that can be used to gauge current and emerging trends in new design objectives and methodologies that address combinatorial optimisation aspects. The new developments in layout research analysed in this study provide a perspective on what the future of the field of study will be like. A tendency to use meta-heuristics like GA, which lean toward multi-objective approaches to layout and material handling system design, is observed.
\end{abstract}

\section{OPSOMMING}

Hierdie artikel bied ' $\mathrm{n}$ hedendaagse oorsig oor die aanwending van die Genetiese Algoritme (GA). DIt is ' $n$ belangrike metodologie vir fasiliteitsuitlegprobleme wat gebruik kan word om die huidige en ontluikende tendense te bepaal in nuwe ontwerpdoelwitte- en metodologieë wat kombinatoriese optimisasie aspekte aanspreek. Die nuwe ontwikkelinge in uitlegnavorsing wat in hierdie artikel ondersoek word, verskaf ' $n$ perspektief op die toekoms van die studieveld. ' $n$ Tendens wat waargeneem word, is om meta-heuristiek soos GA aan te wend wat neig tot multi-doelwit-benaderings vir uitleg- en materiaalhanteringsontwerp.

\footnotetext{
${ }^{1}$ The author was enrolled for an M Tech (Industrial Engineering \& Management) degree in the Department of Industrial Engineering \& Management, West Bengal University of Technology.
} 


\section{INTRODUCTION:}

Facility Layout Design (FLD), also known as plant layout design for manufacturing, has always been an active research area due to its wide range of application and concomitant complexity. This domain is a sub-set and core element of facility planning. FLD can be defined as a fundamental operation that involves planning, designing, and optimisation of the physical arrangement of resources - man, machine, material, and attendant production systems - to streamline production. Such a system, once optimised, also helps to improve quality in many situations. Francis et al. [21] observed that the Facility Layout Problem (FLP) is primarily a design problem. and its optimisation procedure differs significantly from other similar procedures applied to areas of operations, since this involves constraints in the form of geometrical configurations of facilities or space. The strategic role of facility planning and design may be found in the observations of researchers like Tompkins et al. [85], and is also referred to by Wang et al. [77] and Wrennall [79], who note that about 8\% of the United States' gross national product has been spent on new facilities annually since 1955. This estimate does not include the modification of existing facilities.

This paper presents a state-of-the-art review on the application of the Genetic Algorithm as an important methodology used for facility layout problems, and gauges current and emerging trends in new design objectives, algorithms, and methodologies in relation to aspects of combinatorial optimisation. New developments in emerging layout research, as analysed in this study, provide a perspective on the future of the field. A review of the literature and of the methodologies proposed therein, along with their applications in FLP, are presented in Section 2. An analysis of the current and future trends in research is presented in Section 3.

\section{LITERATURE REVIEW}

FLP is a context-driven problem. Depending on the type of material flow, facility layout can be classified into four general groups. They are: fixed position layout, product layout, process layout, and cellular layout using group technology. Generally FLD algorithms are found to be of three types: construction type, improvement type, or hybrid type. Construction type algorithms deal with green field design - that is, fashioning a new layout from scratch ([55] [7] [41] [81]). Existing layouts are modified by improvement type algorithms that accept an existing layout design and design parameters as their inputs, and evolve an improved layout with improved efficiency to facilitate an organisation's objective ([9] [46]). The hybrid type of algorithms incorporates both construction and improvement type algorithms [35]. In this paper, FLD optimisation objectives have been classified into two types: one, a static layout that is designed for long-term planning without considering a variation of product mix and capacity or volume of production over a period; and two, a dynamic layout that is designed to be robust in nature, requiring slight or no change to remain tuned to the variability of production volume and product mix in the long run. A multi-objective layout design varies with the variation of designer dependent objective strength, which may at times suffer from dominated solutions. Thus a mechanism to intensify objectives irrespective of a designer is a good approach to automating layout design systems [70].

From the second half of the previous century to the present era of integrated manufacturing, this problem has evolved with varied shapes and dimensions. To deal with complexities, different methodologies have been introduced to achieve workable solutions. Analytical approaches to this problem were introduced prior to the computer era. Pioneers in this research include Immer [32], Reed [61], [62], Moore [51], Apple [3], and Nadler [53]. Muther [52] brought a new dimension to the solution methodology by introducing Systematic Layout Planning (SLP), which is still recognised in the literature as a basic framework for an analytical approach. Computerised techniques for designing a new layout or improving an existing layout were initiated by classic software for FLD such as CRAFT [4], CORELAP [67], COFAD [76], ALDEP [65], and PLANET [37]. (This listing of the FLD software has been compiled by Singh and Sharma [68]). But the contemporary trend is to use the 
multi-objective approach [63] with meta-heuristics based procedures, as is evident from a survey of the literature; and little research has been reported using the conventional heuristic approach. Meta-heuristic procedures - the Genetic Algorithm (GA), Tabu Search (TS), Simulated Annealing (SA), Ant Colony Optimization (ACO), Particle Swarm Optimization (PSO), Hybrid system, and the application of virtual reality - have been proposed to optimise layout design. It is found, through the review done here, that GA is used as the solution methodology in nearly $47 \%$ of the articles - that is, almost half of the literature deals with GA-based approaches. So a review of the application of GA in FLP is work that has great potential. A literature review on the application of different methods for FLP is illustrated in Section 2.2 and Section 2.3.

\subsection{Formulation technique}

The basic concepts of various formulation techniques of FLP are discussed in this section. In most cases, a Quadratic Assignment Problem (QAP) model is used as the objective function presentation or the formulation technique ([64] [59] [66] [38] [27] [56] [82] [19] [73] [55] [41] [50] [46]). Mixed Integer Programming (MIP) ([63] [15] [80] [44] [22]) as a formulation technique can be placed second to QAP, and is followed by Non Linear Mixed Integer Programming (NLMIP) [7] and Non Linear Programming (NLP) [6] in the order of frequency of use. In general, two classes of objective function representation are considered: adjacency-based, and distance-based.

Adjacency-based function parameters are closeness ratings of departments and a decision variable. Closeness rating is the numerical value corresponding to the closeness rank order, typically presented as $r_{i j}$. A decision variable, typically represented as $x_{i j}$, takes a 1 or 0 value depending on whether department $i$ is adjacent to department $j$ or not. The following equation (1) depicts an adjacency-based representation of objective function for FLP ([68] [49]).

$$
\max \sum_{i}^{n} \sum_{j}^{n}\left(r_{i j}\right) x_{i j}
$$

where

$i=1,2 \ldots n$

$\mathrm{n}=$ total number of departments

$j=1,2 \ldots n$

Functional parameters associated with distance-based computation are (a) distance between departments in a predefined (often Euclidian or eectilinear) distance measurement metric, (b) frequency of material flow between departments, and (c) unit cost of handling material between departments. The distance between a pair of departments, department $i$ and department $j$, is denoted as $d_{i j}$. Frequency of material flow between department $i$ and department $j$ is typically represented as $f_{i j}$ and the cost of interdepartmental material handling is denoted as $c_{i j}$. The following equation (2) portrays a distance-based objective function for FLP [49].

$$
\min \sum_{i}^{n} \sum_{j}^{n}\left(f_{i j} c_{i j}\right) d_{i j}
$$

where

$i=1,2 . . . n$

$\mathrm{n}=$ total number of departments

$j=1,2 \ldots n$

In the case of a multi-floor layout, both the horizontal and vertical material handling costs and distances included in the objective function are employed (see equation 3 ) where the 
superscript notations ' $\mathrm{H}$ ' and ' $\mathrm{V}$ ' indicate horizontal and vertical movements respectively [49].

$$
\min \sum_{i}^{n} \sum_{j}^{n}\left(c_{i j}^{H} d_{i j}^{H}+c_{i j}^{V} d_{i j}^{V}\right) f_{i j}
$$

where

$i=1,2 \ldots n$

$\mathrm{n}=$ total number of departments

$j=1,2 \ldots n$

The techniques to optimise the above objectives are reviewed in the next sections. GAbased solutions are elucidated in Section 2.2, followed in Section 2.3 by illustrations of methodologies other than GA: exact optimisation methods, SA, TS, ACO, PSO, Graph theoretic, and other approximation methods for FLP.

\subsection{Genetic Algorithm-based method}

The search mechanism of a GA is actually based on the mechanism of natural selection and natural genetics. GA is widely used in optimisation problems due to its robustness [25], and in the recent past has been used as a tool in industrial engineering optimisation problems [23]. A GA consists of five major elements: (a) a genetic representation of the solution, (b) a well-defined mechanism to generate the initial population, (c) a fitness function to evaluate solution quality, (d) genetic operators (crossover and mutation, analogous to the biological operation to generate offspring), and (e) parameter values.

From the literature review undertaken here, it is observed that GA has been used quite often recently as an optimisation tool for FLP. As indicated by Pierreval et al. [57], the application of GA was significant in optimising the QAP formulation for FLP. It is noted that in most cases the minimisation of material handling costs is seen as an objective function ([59] [77] [78] [84] [22] [58]). However, relatively fewer reports address flexibility of layout [18], layout with aisle structures [81] [13], inter- and intra-cell material handling in a cellular layout [80] [38], maximum utilisation of space [41], and minimisation of total traveling distance [42]. Facility dispositions and their geometrical orientations are generally encoded as a slicing tree ordered set of facilities, facility number order, and $x-y$ coordinate maps to generate the initial population ([77] [55] [22] [13]). The difficulties of applying classical crossover mutation operators in FLP were addressed by Al-Hakim [2]. A different problem-specific modified crossover and mutation operation was developed ([59] [77] [18] [81] [13]) to achieve better GA efficiency. The operators have also been modified to preserve elite solutions [13]. Wu et al. [80] tested the response to the problem of different GA crossovers, mutation rates, population sizes, and maximum number of generations.

The easy hybridisation of GA with other algorithms, and its ability to handle constraint by penalisation as a property, has made GA a preferred tool for multi-objective optimisation for FLP. Generally a hybrid GA with SA or TS methods is chosen as the algorithm to optimise multiple objectives, such as material handling cost and space utilisation [41]; placing facilities around an aisle structure and the optimisation of material handling cost [13]; minimisation of material handling cost and re-layout cost [36]; and loop layout in a flexible manufacturing system [8]. In cellular manufacturing, GA has been applied in a cell formation and group layout involving the optimisation of inter- and intra-cell material handling effort [80] [38].

Smith and Heim [72] applied virtual reality (VR) techniques to the FLD process. GA-based solutions are extended by VR [77] [78] or AutoCAD representation [55] to facilitate the visualisation of the solution's quality. 
The findings of the survey of GA-based facility layout literature undertaken in this work are presented in Table 1, where six major objectives selected for a GA-based solution are set out in columns A to F, as follows:
A. Minimising total material handling or flow cost.
B. Minimising size of resulting layout or maximising utilisation of area.
C. Generation of flexible layout.
D. Minimising material handling cost for inter-cell and intra-cell movement.
E. Minimising total rectilinear distance travel for material.
F. Optimisation of aisle structure.

\begin{tabular}{|c|c|c|c|c|c|c|c|}
\hline \multirow[t]{2}{*}{ References } & \multirow[t]{2}{*}{ Modelling technique } & \multicolumn{6}{|c|}{ Objectives } \\
\hline & & $\mathrm{A}$ & $\mathrm{B}$ & $\mathrm{C}$ & D & $\mathrm{E}$ & $\mathrm{F}$ \\
\hline Delmaire et al.[13] & LP & 5 & & & & & \\
\hline Diego-Mas et al.[14] & Slicing Tree & s & & & & & \\
\hline Dunker et al. [17] & DP & J & & & & & \\
\hline Eklund et al.[18] & MIP & 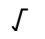 & & s & & & \\
\hline El-Baz [19] & QAP & 5 & & & & & \\
\hline Gau \& Meller [22] & MIP & 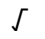 & & & & & \\
\hline Hicks [30] & $\begin{array}{l}\text { Agglomerative } \\
\text { Clustering }\end{array}$ & & & & & s & \\
\hline Hu \& Wang [31] & QAP & s & J & & & & \\
\hline Kochhar \& Heragu [36] & MIP & 5 & & J & & & \\
\hline Kulkarni \& Shanker [38] & QAP & s & & & & & \\
\hline Lee \& Lee [41] & QAP & s & J & & & & \\
\hline Liu \& Li [44] & MIP & s & & & & & \\
\hline Longo et al. [45] & QAP & 厂 & & & & & \\
\hline Osman et al. [55] & QAP & s & & & & & \\
\hline Rajasekharan et al. [58] & MIP & s & & & & & \\
\hline Ramkumar et al. [59] & QAP & s & & & & & \\
\hline Wang et al. [77] & Simulation & s & & & & & \\
\hline Wang et al. [78] & $\begin{array}{l}\text { Simulation and } \\
\text { Virtual Reality }\end{array}$ & r & & & & & \\
\hline Wu \& Appleton [81] & QAP & L & & & & & J \\
\hline Wu et al. [80] & MIP & L & & & J & & \\
\hline
\end{tabular}

Table 1: Techniques and objectives of GA in FLP

\subsection{Other optimisation methods}

The "branch and bound" technique is one exact optimisation method that has been used in FLP, and it provides a single solution using the QAP model.

SA is a stochastic search process based on the concept of 'annealing' [12]. In the case of a single objective optimisation problem, SA is guaranteed to converge in asymptotic time, though the computational time grows exponentially as the size of the problem increases [12].

TS is an iterative meta-heuristic method where at each iteration, the current solution moves to the neighborhood point comprising the smallest value with respect to the objective function. One of the main components of TS is its adaptive memory, which creates a more flexible search behaviour for responsive exploration [24].

The ant colony optimisation and particle swarm optimisation approaches are based on the intelligent behaviour of ants and of particle swarms in finding the optimal travel path between facilities. The main concept is self-organising behaviour, translated into the ability to trace the shortest path between two location points and bypassing any obstacle on the way - as used by ants - as a discrete optimisation problem [16]. This method uses a trail of pheromones to find the optimum path. 


\begin{tabular}{|c|c|c|c|c|c|c|c|c|c|c|c|}
\hline \multirow[t]{2}{*}{ References } & \multirow[t]{2}{*}{ Methodology } & \multirow{2}{*}{$\begin{array}{l}\text { Modelling } \\
\text { Technique }\end{array}$} & \multicolumn{9}{|c|}{ Objectives } \\
\hline & & & $\mathrm{A}$ & $B$ & C & $\mathrm{D}$ & $\mathrm{E}$ & $\mathrm{F}$ & $\mathrm{G}$ & $\mathrm{H}$ & 1 \\
\hline $\begin{array}{l}\text { Abdinnour-Helm \& } \\
\text { Hadley [1] }\end{array}$ & TS & Graph partitioning & 5 & & & & & & & & \\
\hline Bhowmik [5] & $\begin{array}{l}\text { Exact } \\
\text { optimisation }\end{array}$ & Cluster Analysis & 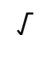 & & & & & & & & \\
\hline Castillo \& Peters [7] & SA & NLMIP & 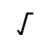 & & & & & & & & \\
\hline Chiang [9] & TS & QAP & 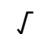 & & & & & & & & \\
\hline Dong et al. [15] & SA & MIP & & $\checkmark$ & & & & & & & \\
\hline Hani et al. [27] & $\mathrm{ACO}$ & QAP & 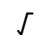 & & & & & & & & \\
\hline Hardin \& Usher [28] & PSO & QAP & 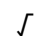 & & & & & & & & \\
\hline Ioannou [33] & SA & IP & & & & s & s & & & & \\
\hline Matsuzaki et al. [46] & SA & $\begin{array}{l}\text { QAP and } \\
\text { Slicing Tree }\end{array}$ & 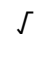 & & & & & & s & & \\
\hline $\begin{array}{l}\text { McKendall Jr.\& } \\
\text { Hakobyan [47] }\end{array}$ & TS & MILP & 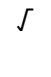 & $\checkmark$ & & & & & & & \\
\hline Mir \& Imam [50] & SA & QAP & 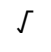 & & & & & & & & \\
\hline Öncan \& Altınel [54] & $\begin{array}{l}\text { Exact } \\
\text { optimisation }\end{array}$ & BILP and DP & 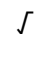 & & & & & & & & \\
\hline Paul et al. [56] & PSO & QAP & 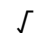 & & & & & & & & \\
\hline Ramkumar et al. [60] & $\mathrm{ACO}$ & QAP & 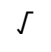 & & & & & & & & \\
\hline Şahin \& Türkbey [63] & SA & MIP & & & & & & ऽ & & & \\
\hline Scholz et al.[64] & TS & QAP & 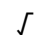 & & & & & & & & J \\
\hline Seo et al.[66] & TS & QAP & 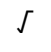 & & & & & & & & \\
\hline Singh [71] & $\begin{array}{l}\text { Exact } \\
\text { optimisation }\end{array}$ & LAP & $\checkmark$ & & & & & & & & \\
\hline Singh \& Sharma [69] & SA & QAP & 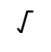 & & & & & & & & \\
\hline Solimanpur et al. [73] & $\mathrm{ACO}$ & QAP & $\checkmark$ & & & & & & & & \\
\hline Sugiyono [74] & SA and TS & $\begin{array}{l}\text { Bond Energy } \\
\text { Algorithm }\end{array}$ & $\checkmark$ & & s & & & & & & \\
\hline $\begin{array}{l}\text { Teo \& Ponnambalam } \\
\text { [75] }\end{array}$ & $\mathrm{ACO}$ and $\mathrm{PSO}$ & NLP & 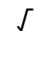 & & & & & & & & \\
\hline Yang et al. [83] & TS & UMNFP & 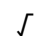 & & & & & & & & \\
\hline Yang et al. [82] & SA & MIP & & & & & & & & $J$ & \\
\hline
\end{tabular}

Table 2: Techniques and objectives of non-GA methods in FLP

Generally graph theoretical methods are used to generate a block layout. The design of a planner graph with proper adjacencies helps the designer to map activity relationships to a block layout [21]. In constructing a cut-tree [34], spanning planar sub-graphs [26] are deployed to optimise the flow path of material. A proximity-based method has also been applied by Cimikowski \& Mooney [11] to maximise the adjacency of a graph theoretical model of FLP. Difficulties in using graph theory in FLD were reported by Francis et al. [21]; and due to its inherent limitations, the application of this methodology has declined in the recent past, as observed in the present study. Exhaustive discussion of the application of graph theory in FLP is illustrated by Hassan \& Hogg [29], Foulds [20].

Apart from graph theory, a few other reports to be mentioned for a comprehensive analysis are the heuristic methods proposed by Cimikowski \& Mooney [10] [11], Meller [48], 
Lacksonen [40], Lin et al. [43], Kumar et al. [39]. No detailed discussion is necessary, as no major work has been reported recently.

A survey of the techniques and objectives of non-GA methods in FLP is shown in Table 2, where selected major objectives are set out in columns A to I, as follows:

A. Minimising material handling cost.

B. Minimising re-layout cost.

C. Optimising total area and stochastic level of production.

D. Vehicle routing.

E. Optimising fixed and variable cost of production.

F. Minimising material handling and total closeness rating score.

G. Optimising number and location of elevators.

H. Material flow path design.

I. Minimising size of resulting layout, or maximising utilisation of area.

\section{CURRENT TRENDS AND FUTURE SCOPE OF WORK}

From this review, the advances in using GA, SA, TS, ACO and PSO to optimise multiobjective FLP are noted where the use of GA is most significant. The emphasis on optimisation modalities for dynamic facility layout to meet space requirements and reducing re-layout cost is also noted, while the basic consideration of material handling cost continues to be important. Depending on the variability of objectives and methodologies, it can be noted that FLPs deal with a wider range of factors that need to be considered. The future scope of designing robust facility layouts is likely to include the application of hybrid techniques such as meta-heuristics and Al for prioritising the objectives and subsequent optimisation; the generation of hybrid layout, independent of the designer's intervention; and the application of 'parallel GA'. An exhaustive comparison between various multi-objective approaches to FLP needs to be undertaken. Thus research possibilities along the above lines should be explored.

\section{CONCLUSION}

This review of the application of GA in FLD in a manufacturing environment has been carried out on various algorithms to solve FLP. These are discussed, and the objectives of their modelling techniques are summarised and tabulated for easy reference. Finally, the future scope of research in this domain is also suggested.

\section{REFERENCES:}

[1] Abdinnour-Helm, S., Hadley, S.W. 2000. Tabu search based heuristics for multifloor facility layout, International Journal of Production Research, 38(2), pp 365383.

[2] Al-Hakim, L. 2000. On solving facility layout problems using genetic algorithms, International Journal of Production Research, 38(11), pp 2573-2582.

[3] Apple, J.M. 1963. Plant layout and material handling, Ronald Press Company.

[4] Armour, G.C. \& Buffa, E.S. 1963. A heuristic algorithm and simulation approach to relative allocation of facilities, Management Science, 9, pp 294-309.

[5] Bhowmik, R. 2008. An approach to the facility layout design optimization, International Journal of Computer Science and Network Security, 8(4), pp 212-220.

[6] Camp, D.J.V., Carter M.W. \& A. Vannelli. 1991. A nonlinear optimization approach for solving facility layout problems, European Journal of Operational Research, 57, pp 174-189.

[7] Castillo, I. \& Peters, B.A. 2003. An extended distance-based facility layout problem, International Journal of Production Research, 41(11), pp 2451- 2479.

[8] Cheng, R., Gen, M. \& Tosawa, T. 1996. Genetic algorithms for designing loop layout manufacturing systems, Computers \& Industrial Engineering, 31(3), pp 587-591. 
[9] Chiang, W. 2001. Visual facility layout design system, International Journal of Production Research, 39(9), pp 1811-1836.

[10] Cimikowski, R. \& Mooney, E. 1995. Heuristics for a new model of facility layout, Computers \& Industrial Engineering, 29(1), pp 273-277.

[11] Cimikowski, R. \& Mooney, E. 1997. Proximity-based adjacency determination for facility layout, Computers \& Industrial Engineering, 32(2), pp 341-349.

[12] Coello, C.A., Lamont, G.B. \& van Veldhuizen, D.A. 2007. Evolutionary algorithms for solving multi-objective problems, Springer.

[13] Delmaire, H., Langevin, A. \& Riopel, D. 1997. Skeleton-based facility layout design using genetic algorithms, Annals of Operations Research, 69, pp 85-104.

[14] Diego-Mas, J.A., Santamarina-Siurana, M.C., Alcaide-Marzal, J. \& CloquellBallester, V.A. 2009. Solving facility layout problems with strict geometric constraints using a two-phase genetic algorithm, International Journal of Production Research, 47 (6), pp 1679-1693.

[15] Dong, M., Wu, C. \& Hou, F. 2009. Shortest path based simulated annealing algorithm for dynamic facility layout problem under dynamic business environment, Expert Systems with Applications, doi: 10.1016/j.eswa.2009.02.091.

[16] Dorigo, M. \& Stuitzle, T. 2004. Ant colony optimization, Massachusetts Institute of Technology Press.

[17] Dunker, T., Radons, G. \& Westkamper, E. 2005. Combining evolutionary computation and dynamic programming for solving a dynamic facility layout problem, European Journal of Operational Research, 165, pp 55-69.

[18] Eklund, N.H.W., Embrechts, M.J. \& Goetschalckx, M. 2006. Efficient chromosome encoding and problem-specific mutation methods for the flexible bay facility layout problem, IEEE Transactions on Systems, Man, and Cybernetics-PART C: Applications and Reviews, 36(4), pp 495-502.

[19] El-Baz, M.A. 2004. A genetic algorithm for facility layout problems of different manufacturing environments, Computers \& Industrial Engineering, 47, pp 233-246.

[20] Foulds, L.R. 1991. Graph theory and applications, Springer.

[21] Francis, R.L., McGinnis, L.F. \& White, Jr. J.A. 1992. Facility layout and location: An analytical approach, Prentice- Hall Inc.

[22] Gau, K.Y. \& Meller, R.D. 1999. An iterative facility layout algorithm, International Journal of Production Research, 37(16), pp 3739-3758.

[23] Gen, M. \& Cheng, R. 2000. Genetic algorithms and engineering optimization, John Wiley \& Sons, Inc.

[24] Glover, F. \& Laguna, M. 1997. Tabu search, Kluwer Academic Publishers.

[25] Goldberg, D.E. 1989. Genetic algorithms in search, optimization \& machine learning, Pearson Education, Inc.

[26] Goldschmidt, O., Takvorian, A. \& Yu, G. 1996. On finding a biconnected spanning planar subgraph with applications to the facilities layout problem, European Journal of Operational Research, 94, pp 97-105.

[27] Hani, Y., Amodeo, L., Yalaoui, F. \& Chen, H. 2007. Ant colony optimization for solving an industrial layout problem, European Journal of Operational Research, 183, pp 633-642.

[28] Hardin, C.T. \& Usher, J.S. 2005. In: -'Facility layout using swarm intelligence' Swarm Intelligence Symposium, 2005. SIS2005. Proceedings 2005 IEEE, pp 424-427.

[29] Hassan, M.M.D. \& Hogg, G.L. 1987. A review of graph theory applications to the facilities layout problem, Omega, 15, pp 291-300.

[30] Hicks, C. 2004. A genetic algorithm tool for designing manufacturing facilities in the capital goods industry, International Journal of Production Economics, 90, pp 199211.

[31] Hu, M.H. \& Wang, M.J. 2004. Using genetic algorithms on facilities layout problems, International Journal of Advance Manufacturing Technology, 23, pp 301-310.

[32] Immer, J.R. 1953. Material handling, McGraw-Hill Book Company Inc.

[33] Ioannou, G. 2007. An integrated model and a decomposition-based approach for concurrent layout and material handling system design, Computers \& Industrial Engineering, 52, pp 459-485. 
[34] Kim, C., Foote, B.L. \& Pulat, P.S. 1995. Cut-tree construction for facility layout, Computers \& Industrial Engineering, 28(4), pp 721-730.

[35] Kim, J. \& Kim, Y. 2000. Layout planning for facilities with fixed shapes and input and output points, International Journal of Production Research, 38(18), pp 46354653.

[36] Kochhar, J.S. \& Heragu, S.S. 1999. Facility layout design in a changing environment, International Journal of Production Research, 37(11), pp 2429-2446.

[37] Konz, S. 1985. Facility design, Wiley.

[38] Kulkarni, P.C. \& Shanker, K. 2007. A genetic Algorithm for Layout problems in Cellular Manufacturing systems In: proceedings of the IEEE IEEM, pp 694-698.

[39] Kumar, K.R., Hadjinicola, G.C. \& Lin, T. 1995. A heuristic procedure for the singlerow facility layout problem, European Journal of Operational Research, 87, pp 6573.

[40] Lacksonen, T.A. 1997. Preprocessing for static and dynamic facility layout problems, International Journal of Production Research, 35(4), pp 1095-1106.

[41] Lee, Y.H. \& Lee, M.H.. 2002. A shape-based block layout approach to facility layout problems using hybrid genetic algorithm, Computers \& Industrial Engineering, 42, pp 237-248.

[42] Li, H. \& Love, P.E.D. 2000. Genetic search for solving construction site-level unequal-area facility layout problems, Automation in Construction, 9, pp 217-226.

[43] Lin, J., Foote, B., Pulat, S., Chang, C. \& Cheung, J.Y. 1996. Solving the failure-tofit problem for plant layout: By changing department shapes and sizes, European Journal of Operational Research, 89, pp 135-146.

[44] Liu, X. \& Li, X. 2006. An Improved Genetic Algorithms-based Approach on Supply Chainoriented Facility Layout Scheduling System In: Proceedings of the 6th World Congress on Intelligent Control and Automation, China.

[45] Longo, F., Mirabelli, G. \& Papoff, E. 2005. Material flow analysis and plant lay-out optimization of a manufacturing system, IEEE Workshop on Intelligent Data Acquisition and Advanced Computing Systems: Technology and Applications 5-7 September 2005, Sofia, Bulgaria.

[46] Matsuzaki, K., Irohara, T. \& Yoshimoto, K. 1999. Heuristic algorithm to solve the multi-floor layout problem with the consideration of elevator utilization, Computers \& Industrial Engineering, 36, pp 487-502.

[47] McKendall, A.R. \& Hakobyan, A. 2009. Heuristics for the dynamic facility layout problem with unequal-area departments, European Journal of Operational Research, doi:10.1016/j.ejor.2009.02.028

[48] Meller, R.D. 1997. The multi-bay manufacturing facility layout problem, International Journal of Production Research, 35(5), pp 1229-1237.

[49] Meller, R.D. \& Gau, K. 1996. The facility layout problem: Recent and emerging trends and perspectives, Journal of Manufacturing Systems, 15(5), pp 351-366.

[50] Mir, M. \& Imam, M.H. 2001. A hybrid optimization approach for layout design of unequal-area facilities, Computers \& Industrial Engineering, 39, pp 49-63.

[51] Moore, J.M. 1962. Plant layout and design, MacMillan Publishing Company Inc.

[52] Muther, R. 1973. Systematic layout planning, CBI Publishing Company Inc.

[53] Nadler, G. 1967. Work system design: The IDEALS Concept, Richard D. Irwin.

[54] Öncan, T. \& Altınel, I.K. 2008. Exact solution procedures for the balanced unidirectional cyclic layout problem, European Journal of Operational Research, 189, pp 609-623.

[55] Osman, H.M., Georgy, M.E. \& Ibrahim, M.E. 2003. A hybrid CAD-based construction site layout planning system using genetic algorithms, Automation in Construction, 12, pp 749-764.

[56] Paul, R.C., Asokan, P. \& Prabhakar, V.I. 2006. A solution to the facility layout problem having passages and inner structure walls using particle swarm optimization, International Journal of Advanced Manufacturing Technology, 29, pp 766-771.

[57] Pierreval, H., Caux, C., Paris, J.L. \& Viguier, F. 2003. Evolutionary approaches to the design and organization of manufacturing systems, Computers \& Industrial Engineering, 44, pp 339-364. 
[58] Rajasekharan, M., Peters, B.A. \& Yang, T. 1998. A genetic algorithm for facility layout design in flexible manufacturing systems, International Journal of Production Research, 36(1), pp 95-110.

[59] Ramkumar, A.S., Ponnambalam, S.G. \& Jawahar, N. 2009. A new iterated fast local search heuristic for solving QAP formulation in facility layout design, Robotics and Computer-Integrated Manufacturing, 25, pp 620-629.

[60] Ramkumar, A.S., Ponnambalam, S.G. \& Jawahar, N. 2008. A population-based hybrid ant system for quadratic assignment formulations in facility layout design, International Journal of Advanced Manufacturing Technology. DOI 10.1007/s00170008-1849-y.

[61] Reed, R. 1967. Plant location, layout, and maintenance, Richard D. Irwin Inc.

[62] Reed, R. Jr. 1961. Plant layout: Factors, principles, and techniques, Richard D. Irwin Inc.

[63] Şahin, R. \& Türkbey, 0. 2009. A simulated annealing algorithm to find approximate Pareto optimal solutions for the multi-objective facility layout problem, International Journal of Advanced Manufacturing Technology, 41, pp 1003-1018.

[64] Scholz, D., Petrick, A. \& Domschke, W. 2009. STaTS: A Slicing Tree and Tabu Search based heuristic for the unequal area facility layout problem, European Journal of Operational Research, 197, pp 166-178.

[65] Seehof, J.M. \& Evans, W.O. 1967. Automated layout design program, The Journal of Industrial Engineering, 18(12), pp 690-695.

[66] Seo, Y., Sheen, D., Moon, C. \& Kim, T. 2006. Integrated design of workcells and unidirectional flowpath layout, Computers \& Industrial Engineering, 51, pp 142-153.

[67] Sepponen, R. 1969. CORELAP8 User Manual, Department of Industrial Engineering, Northeastern University, Boston.

[68] Singh, S.P. \& Sharma, R.R.K. 2006. A review of different approaches to the facility layout problems, International Journal of Advanced Manufacturing Technology, 30, pp 425-433.

[69] Singh, S.P. \& Sharma, R.R.K.. 2007. Two-level modified simulated annealing based approach for solving facility layout problem, International Journal of Production Research, 46(13), pp 3563-3582.

[70] Singh, S.P. \& Singh, V.K. 2009. An improved heuristic approach for multi-objective facility layout problem, International Journal of Production Research, 2010, vol. 48, no. 4, pp. 1171-1194.

[71] Singh, S.P. 2009. An Approximate Algorithm to Solve Facility Layout Problem, In: IEEE International Advance Computing Conference (IACC 2009), Patiala, India, 6-7 March 2009.

[72] Smith, R.P. \& Heim, J.A. 1999. Virtual facility layout design: The value of an interactive three-dimensional representation, International Journal of Production Research, 37(17), pp 3941-3957.

[73] Solimanpur, M., Vrat, P. \& Shankar, R. 2004. Ant colony optimization algorithm to the inter-cell layout problem in cellular manufacturing, European Journal of Operational Research, 157, pp 592-606.

[74] Sugiyono, A. 2006. Cellular Manufacturing System Application On Redesign Production Layout With Using Heuristics Algorithm, In: 2006 IEEE International Conference on Management of Innovation and Technology, pp 940-944.

[75] Teo, Y.T. \& Ponnambalam, S.G. 2008. A Hybrid ACO/PSO Heuristic to solve Single Row Layout Problem, In: 4th IEEE Conference on Automation Science and Engineering, Key Bridge Marriott, Washington DC, USA, pp 597-602.

[76] Tompkins, J.A. \& Reed, Jr. R. 1976. An applied model for the facilities design problem, International Journal of Production Research, 14(5), pp 583-595.

[77] Wang, G., Yan, Y., Zhang, X., Shangguan, J. \& Xiao, Y. 2008a. Integrating Simulation Optimization with VR for Facility Layout Evaluation, In: Proceedings of the 2008 IEEE IEEM.

[78] Wang, G., Yan, Y., Zhang, X., Shangguan, J. \& Xiao, Y. 2008b. A Simulation Optimization Approach for Facility Layout Problem, In: 2008 International 
Conference on Information Management, Innovation Management and Industrial Engineering.

[79] Wrennall, W. 2001. Facilities layout and design, in K. B. Zandin (ed.), Maynard's Industrial Engineering Handbook, Chapter 8.2, pp 8.21-8.62, McGraw-Hill Book Company Inc.

[80] Wu, X., Chu, C., Wang, Y. \& Yan, W. 2007. A genetic algorithm for cellular manufacturing design and layout, European Journal of Operational Research, 181, pp 156-167.

[81] Wu, Y. \& Appleton, E. 2002. The optimization of block layout and aisle structure by a genetic algorithm, Computers \& Industrial Engineering, 41, pp 371-387.

[82] Yang, T., Peters, B.A. \& Tu, M. 2005. Layout design for flexible manufacturing systems considering single-loop directional flow patterns, European Journal of Operational Research, 164, pp 440-455.

[83] Yang, T., Rajasekharan, M. \& Peters, B.A. 1999. Semiconductor fabrication facility design using a hybrid search methodology, Computers \& Industrial Engineering, 36, pp 565-583.

[84] Zhang, G.Q., Xue, J. \& Lai, K.K. 2002. A class of genetic algorithm for multiplelevel warehouse layout problems, International Journal of Production Research, 40(3), pp 731- 744.

[85] Tompkins, J.A., White, J.A., Bozer, Y.\& Tanchoco, J.M.A. 2003. Facilities planning, $3^{\text {rd }}$ edition, John Wiley \& Sons. 
http://sajie.journals.ac.za 